\title{
Correction to: Quadratus Lumborum Block: a Technical Review
}

\section{Avni Gupta $^{1} \cdot$ Rakesh Sondekoppam $^{2} \cdot$ Hari Kalagara $^{3}$}

Published online: 25 November 2019

(C) The Author(s) 2019

\section{Correction to: Current Anesthesiology Reports (2019) 9(3):257-262 https://doi.org/10.1007/s40140-019-00338-9}

The article Quadratus Lumborum Block: a Technical Review, written by Avni Gupta, Rakesh Sondekoppam and Hari Kalagara, was originally published Online First without Open Access. After publication in volume 9, issue 3, page 257-262 the author decided to opt for Open Choice and to make the article an Open Access publication. Therefore, the copyright of the article has been changed to $($ The Author(s) 2019 and the article is forthwith distributed under the terms of the Creative Commons Attribution 4.0 International License (http://creativecommons.org/licenses/by/4.0/), which permits use, duplication, adaptation, distribution and reproduction in any medium or format, as long as you give appropriate credit to the original author(s) and the source, provide a link to the Creative Commons license, and indicate if changes were made.

The original article has been corrected.

Open Access This article is distributed under the terms of the Creative Commons Attribution 4.0 International License (http:// creativecommons.org/licenses/by/4.0/), which permits unrestricted use, distribution, and reproduction in any medium, provided you give appropriate credit to the original author(s) and the source, provide a link to the Creative Commons license, and indicate if changes were made.

Publisher's Note Springer Nature remains neutral with regard to jurisdictional claims in published maps and institutional affiliations.

The online version of the original article can be found at https://oi.org/ 10.1007/s40140-019-00338-9

Hari Kalagara

hkalagara@uabmc.edu

1 Millennium Pain Center, Unity Point Health-Methodist Hospital, Peoria, IL, USA

2 University of Alberta Hospital, Edmonton, Alberta, Canada

3 Department of Anesthesiology, The University of Alabama at Birmingham (UAB), Birmingham, AL, USA 